\title{
Botanical profile of bee pollen from the southern coastal region of Bahia, Brazil
}

\author{
Marcos da Costa Dórea ${ }^{1}$, Jaílson Santos de Novais ${ }^{2,3}$ and Francisco de Assis Ribeiro dos Santos ${ }^{1}$
}

Recebido em 23/03/2010. Aceito em 15/06/2010

\begin{abstract}
RESUMO - (Perfil botânico do pólen apícola proveniente do Litoral Sul da Bahia, Brasil). O presente trabalho teve por objetivo identificar a origem botânica das bolotas de pólen coletadas pelas abelhas Apis mellifera L. no município de Canavieiras, Bahia, gerando uma lista de plantas poliníferas pertencentes ao bioma Mata Atlântica e importantes para o desenvolvimento da apicultura regional. Foram analisadas palinologicamente 35 amostras de pólen apícola, utilizando-se o processo de acetólise para, em seguida, serem feitas análises qualitativas e quantitativas. Os resultados revelaram que os tipos polínicos Elaeis $(23,99 \%)$, Mimosa pudica $(22,78 \%)$ e Cecropia $(13,68 \%)$ foram os mais abundantes no pólen apícola analisado. Estes tipos polínicos também apresentaram as maiores frequências relativas de todo o material estudado e representam importantes plantas fontes de pólen para as abelhas na área estudada. Palavras-chave: apicultura, Apis mellifera, Mata Atlântica, melissopalinologia, tipo polínico
\end{abstract}

ABSTRACT - (Botanical profile of bee pollen from the southern coastal region of Bahia, Brazil). This paper aims to identify the botanical origin of pollen loads collected by Apis mellifera L. in Canavieiras municipality, Bahia state. It provides a list of polliniferous plant species from the Atlantic Forest biome that are important for the development of regional apiculture. Using the acetolysis method, 35 bee-pollen samples were analyzed qualitatively and quantitatively. Results showed that pollen types Elaeis (23.99\%), Mimosa pudica $(22.78 \%)$ and Cecropia $(13.68 \%)$ were the most abundant among the samples. These also showed the highest relative frequencies of the material studied and were important pollen sources for bees in the study area.

Key words: Apis mellifera, Atlantic Forest, beekeeping, melissopalynology, pollen type

\section{Introduction}

Pollen is an interesting subject for apiculture. Bees harvest the pollen grains as loads, transporting them to hives and storing them in cells a long way from the honeycombs. This product will be used for feeding, especially of the larvae. The pollen grains are also good indicators of the botanical and geographical origin of bee products (Borges et al. 2006).

The literature is still poor in studies on palynological characterization of pollen loads carried by honeybees. For Bahia state, there are a few works such as Ramalho et al. (2007) and Novais et al. (2009).

Most palynological studies are focused on honey analyses and pollen characterization of nectariferous plants. In Bahia, pollen analysis of honey is also scarce in the specialized literature (for example: Carvalho et al. 2001; Santos Jr. \& Santos 2003; Novais et al. 2006; Oliveira et al. 2010).

According to Wiese (1985), knowing the bee flora is an important step towards rational exploitation and conservation of bees, contributing to apiary management, as well as identification, preservation and multiplication of plant species that are most important for apiculture in an area.

The prominence of the Brazilian Northeast with its high extractive production of bee products contrasts with the local trade of this production, which has low market values. With botanical certification it is possible to increase these values and, therefore, improve social and economic conditions of agricultural workers, especially beekeepers.

Although honey has been the most widespread bee product, the bee pollen trade is undergoing expressive growth. The municipality of Canavieiras, Bahia state (BA), stands out on the national scene. The quantity and quality of the bee pollen produced in this municipality has attracted increased attention for Brazilian apiculture.

This work aims to identify the botanical origin of the pollen loads collected by Apis mellifera L. in Canavieiras (BA), and to give scientific support to local cooperatives of beekeepers by indicating important plants for the development of regional apiculture, through identification of pollen types.

\section{Material and methods}

The municipality of Canavieiras ( $\left.15^{\circ} 41^{\prime} \mathrm{S}, 38^{\circ} 57^{\prime} \mathrm{W}\right)$, located in the "Litoral Sul" economic micro-region of Bahia state, is characterized by ample mangrove areas, but also has large tracts of forest, restinga and dune vegetation, with emphasis on palms (Arecaceae). Each of these ecosystems has a rich flora with polliniferous and nectariferous plant species, which are important for apiculture. Flowering time of these species covers the entire year, peaking between August and September (BAHIA 2002).

The material examined was supplied by the Beekeepers Association of Canavieiras (ACAP), between 2002 (samples 01-06) and 2003 (samples 0735). Thirty-five dehydrated bee pollen samples, regulary found in commerce were analyzed. Each 5 -grame sample was dissolved in $25 \mathrm{~mL}$ of distilled water, following the methodology of Alvarado \& Rueda (1985), with some modifications. After complete homogenization of the mixture, $2 \mathrm{~mL}$ from

\footnotetext{
1 Universidade Estadual de Feira de Santana, Departamento de Ciências Biológicas, Laboratório de Micromorfologia Vegetal, Feira de Santana, BA, Brasil

2 Universidade Federal do Oeste do Pará, Centro de Formação Interdisciplinar, Santarém, PA, Brasil

3 Author for correspondence: novais.js@gmail.com
} 
each sample were taken and submitted to the acetolysis method (Erdtman 1960). The sediment was mounted on slides in glycerin jelly (stained with safranine) and sealed with paraffin wax.

For each sample five slides were provided. Subsequently qualitative and quantitative analyses of the pollen grains were carried out. For the qualitative analysis, exploratory observations were made to identify the main pollen types present, which were botanically classified by the palynological literature available (Roubik \& Moreno 1991; Lima et al. 2008). Also comparisons were made of some pollen types encountered in the samples with a pollen reference library for different areas in Bahia state.

For the quantitative analysis, 1,500 pollen grains per sample were counted (Vergeron 1964). Then relative and average abundances and relative frequency of the pollen grains in the samples were calculated. According to Louveaux et al. (1978), if 1,200 pollen grains are counted, the percentages have an accuracy of $1 \%$ and the use of digits after the decimal point is not justified. Pollen types with abundance less than $1 \%$ were considered as "present".

\section{Results and discussion}

The qualitative analysis revealed 46 pollen types whose botanical affinity was established at least to family level. Leguminosae (9) (Mimosoideae, 5 and Papilionoideae, 4), Asteraceae (4), Euphorbiaceae (4), and Scrophulariaceae (4) had the highest richness of pollen types. All other families were represented by one pollen type, except Myrtaceae with 3 types, and Anacardiaceae and Sapindaceae, 2 pollen types each (Tab. 1).

Determination of the botanical family using pollen morphology is not difficult. However, it is not so easy to distinguish genera using only pollen grain characteristics. In most cases, it is not possible to establish the plant species, so it is necessary to recognize only pollen type (Joosten \& De Klerk 2002).

Of the 35 samples analyzed, 13 had all pollen types identified. Nevertheless, 7 samples had some unidentified pollen types, whose relative abundance varied from $1.33 \%$ (sample 02 ) to $16.47 \%$ (sample 23); in 14 other samples, relative abundance was very low for the unidentified pollen types, $<1 \%$ (Tab. 1).

The difficulty in identifying the botanical affinity of a pollen grain is linked to the knowledge of the regional flora (Borges et al. 2006), likewise the acetolysis use, affecting the structure of some grains and making identification a difficult process. There are also pollen grains from different plant families with similar morphology, like the 3-colp(or)ate and microreticulate pollen, very common among the Angiosperms.

Elaeis (Arecaceae), Cecropia (Cecropiaceae) and Mimosa pudica (Leguminosae-Mimosoideae) pollen types occurred in many samples and also show high abundance values (Tab. 1 and 2).

Other pollen types like Spondias (Anacardiaceae), Eupatorium (Asteraceae), Ricinus (Euphorbiaceae), Centrosema (Leguminosae-Papilionoideae), Eucalyptus (Myrtaceae), Scoparia (Schrophulariaceae), Schrophulariaceae type 1 and Triunfeta (Tiliaceae), in spite of having low relative abundance values (Tab. 2), had values above $1 \%$.

In a review on plants used by bees for collecting trophic resources in Neotropical regions, Ramalho et al.
(1990) verified that the families Anacardiaceae, Arecaceae, Asteraceae, Balsaminaceae, Euphorbiaceae, Fabaceae, Lamiaceae, Leguminosae, Moraceae, Proteaceae, Rubiaceae and Sterculiaceae are important to Apis mellifera. Many of these families were observed in our study with large representation, especially Leguminosae and Asteraceae.

According to Carvalho et al. (1999), the fact that some species present low abundance values $(<1 \%)$ may be related to plant biology factors, such as low pollen production, or linked to the harvest behavior of the bee (indirect collection and/or collected resource). However, it is also possible that pollen grains had accidently contaminated the pollen masses carried during foraging activities, contributing to increase the number of pollen types with low representation.

Despite the botanical diversity in the Atlantic Forest, Camillo \& Garófalo (1989) explain that the exclusion of some species from the list of plants visited by bees may be due either to the fact that the plants do not attract these insects, or the bees may prefer certain supply sources because of the ease of harvesting the reward; likewise the quantity and quality of trophic resources available and interactions with competitors may affect this event.

Eusocial bees are considered to be specialists in high floral densities. They choose the resources from which they can obtain larger quantities of food and so monopolize them, utilizing similar strategies of foraging. In other words, intensive use of few floral resources (Imperatriz-Fonseca et al., 1984). Some authors state that bees have a generalist habit of foraging (for example, Aguiar et al. 2002; Aguiar 2003), but show certain floral preferences (ImperatrizFonseca et al. 1984).

The pollen types Elaeis, Cecropia and Mimosa pudica, respectively, were the most frequent in the samples analyzed (Tab. 2). Elephantopus, Eupatorium and Poaceae types, although few, abundant in the samples where they occurred, presented high relative frequencies, once they were calculated in relation to the totality of the material analyzed.

Some of the pollen types encountered in our samples have been considered important (even when they are found at low frequency) because they are indicators of ecosystems. For example, Alchornea (Euphorbiaceae), Brosimum (Moraceae), Cecropia (Cecropiaceae) and Elaeis (Arecaceae) are indicators of hygrophilous forests (Mori et al. 1983). Also registered were pollen types associated with Myrtaceae species that can be related to the restinga ecosystem and hygrophilous forest.

It is interesting point to out that none of the main pollen types found in the samples were indicators of mangrove vegetation (at least the shrub and tree species), like that related to Avicennia, Laguncularia and Rhizophora species (Silva \& Santos 2009). It is possible that the availability of resources in forest and restinga areas was more attractive to bees, and the apiaries were installed preferentially in those areas.

With reference to Cecropia type (indicator of hygrophilous forest), Marques-Souza et al. (1993) observed in the Amazon 
Table 1. Relative abundance (\%) of the occurrence of pollen types in samples of dehydrated bee pollen from Canavieiras, Bahia state. + , relative abundance less than $1 \%$.

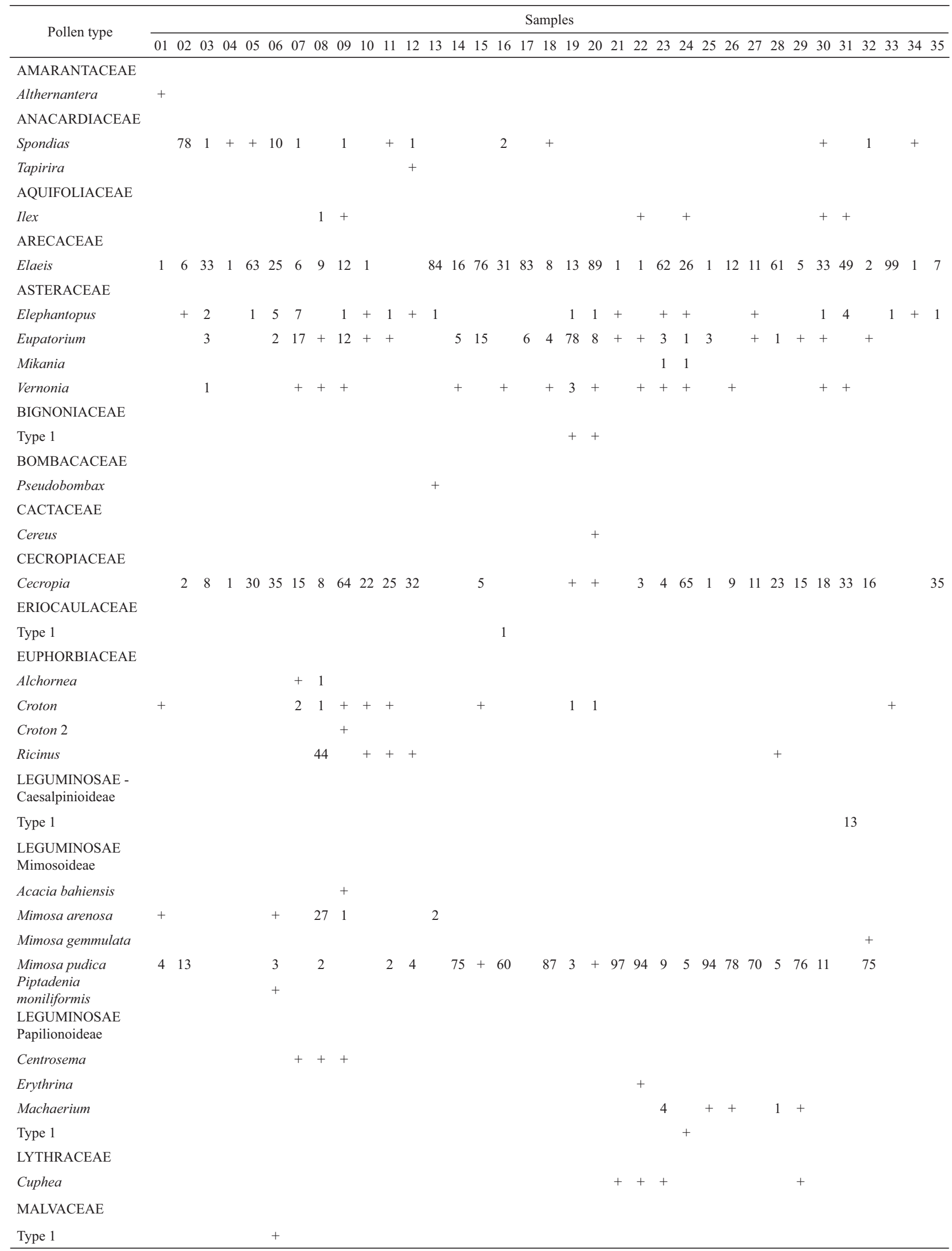


Table 1. Continuation.

\begin{tabular}{|c|c|c|c|c|c|c|c|c|c|c|c|c|c|c|c|c|c|c|c|c|c|c|c|c|c|c|c|c|c|c|c|c|c|c|}
\hline \multirow{2}{*}{ Pollen type } & \multicolumn{34}{|c|}{ Samples } \\
\hline & 01 & 02 & 03 & 04 & 05 & 06 & 07 & 08 & 09 & 10 & 11 & 12 & 13 & 14 & 15 & 16 & 17 & 18 & 19 & 20 & 21 & 22 & 23 & 24 & 25 & 262 & 27 & 28 & 29 & 30 & 31 & 3233 & 34 & 35 \\
\hline Type 1 & & & & & & & 3 & & & 2 & & & 11 & & & & & & & & + & + & & & & & + & & + & & & + & & \\
\hline \multicolumn{35}{|l|}{ MELIACEAE } \\
\hline Guarea & & & & & & & 1 & & & & & & & & & & & & & & & & & & & & & & & & & & & \\
\hline \multicolumn{35}{|l|}{ MORACEAE } \\
\hline Brosimum & & & & & & & & 2 & 1 & 3 & & 7 & & & & & & & 1 & & & & & & + & + & & & & 1 & & & & \\
\hline \multicolumn{35}{|l|}{ MYRTACEAE } \\
\hline Eucalyptus & & & & & & & + & & & 72 & 67 & 50 & 1 & & & 3 & & & & & + & 1 & & + & & + & 7 & + & 3 & 36 & 1 & 3 & 1 & 58 \\
\hline Type 1 & & + & 51 & 98 & 7 & 2 & 1 & + & + & & & & & & & & & + & & & & & & & & & & & & & & & & \\
\hline Psidium & & & & & & & & & & & & & & & & & & & & & & & & & & + & + & & 1 & 1 & & + & & + \\
\hline \multicolumn{35}{|l|}{ PASSIFLORACEAE } \\
\hline Passiflora & & & & & & & & 1 & & & & & & & & & & & & & & & & & & & & & & & & & & \\
\hline \multicolumn{35}{|l|}{ POACEAE } \\
\hline Type 1 & + & & & + & & 1 & 4 & 5 & 1 & 1 & 5 & 5 & 1 & 1 & 4 & 2 & 12 & & + & + & & & 1 & + & & & & & + & & & & & \\
\hline \multicolumn{35}{|l|}{ RUBIACEAE } \\
\hline Borreria & & & + & & & & + & & + & & & & & & & & & & + & + & & + & & & & + & & & & + & 1 & & & \\
\hline \multicolumn{35}{|l|}{ SAPINDACEAE } \\
\hline Allophylus & & & & & & & & & 3 & & & & & & & & & & & & & & & + & & & & & & & & & & \\
\hline Serjania & & & & & & & + & & + & & & & & & & & & & & & & & & & & & & & & & & & & \\
\hline Scoparia & & & & & & & & & & & & & & & & & & & & & & & & & & & & & & & & & 99 & + \\
\hline Type 1 & & & & & & & 5 & & & & & & & & & & & & & & & & & & & & & & & & & & & \\
\hline Type 2 & & & & & & & 36 & & & & & & & & & & & & & & & & & & & & & & & & & & & \\
\hline Type 3 & & & & & & & 2 & & & & & & & & & & & & & & & & & & & & & & & & & & & \\
\hline TILIACEAE & & $\mathrm{b}$ & & & & & & & & & & & & & & & & & & & & & & & & & & & & & & & & \\
\hline Triunfeta & 93 & & & & & & & & & & & & & & & & & & & & & & & & & & & & & & & & & \\
\hline Unidentified types & 1 & 1 & + & + & + & 17 & 1 & + & 3 & & & & & 3 & + & + & & + & + & & + & & 16 & + & + & & & 9 & & + & 1 & 3 & & \\
\hline
\end{tabular}

region that this pollen type represents an invasive species, which quickly substitutes the original vegetation in disturbed areas, serving as an indicator of environmental impact. Other works have referred to the occurrence of this type in bee products and although it had been considered anemophilous, it plays an important role in the geographical demarcation of these products (Moreti et al. 2000; Luz et al. 2007; Modro et al. 2007). This information agrees with our results when we consider that the Cecropia type was one of the most constant among the samples from Canavieiras - a municipality where devastation of the Atlantic Forest is increasing more and more.

\section{Conclusion}

The bee pollen produced in the municipality of Canavieiras is constituted by the association of many pollen types, most of which are related to common species from Atlantic Forest. The pollen spectrum presented here indicates some plant species more important to regional bee pasture, as the species Mimosa pudica (Leguminosae). Palynological analysis provides an additional tool for development of the regional apiculture.

\section{Acknowledgements}

We thank the ACAP for providing the studied samples; the Coordenação de Aperfeiçoamento de Pessoal de Nível Superior (CAPES) by the grant to MCD; the Conselho Nacional de Desenvolvimento Científico e Tecnológico (CNPq) by the grants to JSN and FARS.

\section{References}

Aguiar, C.M.L.; Monteiro, V.M.; Santos, G.M.M.; Resende, J.J.; França, F. \& Melo, E. 2002. Plantas visitadas por Apis mellifera (Hymenoptera, Apidae) em uma área de caatinga em Itatim, Bahia, Brasil. Sitientibus série Ciências Biológicas 2: 29-33.

Aguiar, C.M.L. 2003. Utilização de recursos florais por abelhas (Hymenoptera, Apoidea) em uma área de caatinga (Itatim, Bahia, Brasil). Revista Brasileira de Zoologia 20: 457-467. 
Table 2. Average abundance (\%) and average frequency (\%) of pollen types observed in samples of bee pollen from Canavieiras, Bahia state.

\begin{tabular}{|c|c|c|c|}
\hline & Pollen type & Abundance & Frequency \\
\hline Amaranthaceae & Alternanthera & 0.001 & 2.86 \\
\hline Bombacaceae & Pseudobombax & 0.002 & 2.86 \\
\hline Euphorbiaceae & Croton 2 & 0.002 & 2.86 \\
\hline Leguminosae-Mimosoideae & Acacia bahiensis & 0.002 & 2.86 \\
\hline Leguminosae-Mimosoideae & Piptadenia moniliformis & 0.002 & 2.86 \\
\hline Leguminosae-Papilionoideae & Erythrina & 0.006 & 2.86 \\
\hline Anacardiaceae & Tapirira & 0.008 & 2.86 \\
\hline Cactaceae & Cereus & 0.008 & 2.86 \\
\hline Leguminosae-Papilionoideae & Type 1 & 0.009 & 2.86 \\
\hline Leguminosae-Mimosoideae & Mimosa gemmulata & 0.011 & 2.86 \\
\hline Lythraceae & Cuphea & 0.011 & 11.43 \\
\hline Malvaceae & Type 1 & 0.011 & 2.86 \\
\hline Sapindaceae & Serjania & 0.011 & 5.71 \\
\hline Bignoniaceae & Type 1 & 0.013 & 5.71 \\
\hline Meliaceae & Guarea & 0.015 & 2.86 \\
\hline Eriocaulaceae & Type 1 & 0.025 & 2.86 \\
\hline Euphorbiaceae & Alchornea & 0.028 & 5.71 \\
\hline Passifloraceae & Passiflora & 0.034 & 2.86 \\
\hline Scrophulariaceae & Type 3 & 0.043 & 2.86 \\
\hline Asteraceae & Mikania & 0.057 & 5.71 \\
\hline Myrtaceae & Psidium & 0.057 & 17.14 \\
\hline Rubiaceae & Borreria & 0.069 & 25.71 \\
\hline Sapindaceae & Allophylus & 0.073 & 5.71 \\
\hline Scrophulariaceae & Type 1 & 0.129 & 2.86 \\
\hline Euphorbiaceae & Croton & 0.137 & 28.57 \\
\hline Leguminosae-Papilionoideae & Machaerium & 0.154 & 14.28 \\
\hline Asteraceae & Vernonia & 0.168 & 42.86 \\
\hline Aquifoliaceae & Ilex & 0.185 & 17.14 \\
\hline Leguminosae-Caesalpinioideae & Type 1 & 0.358 & 2.86 \\
\hline Moraceae & Brosimum & 0.413 & 22.86 \\
\hline Melastomataceae/Combretaceae & Type 1 & 0.485 & 22.86 \\
\hline Asteraceae & Elephantopus & 0.776 & 60.00 \\
\hline Leguminosae-Mimosoideae & Mimosa arenosa & 0.845 & 14.28 \\
\hline Poaceae & Gramineae & 0.857 & 54.28 \\
\hline Scrophulariaceae & Type 2 & 1.024 & 2.86 \\
\hline Euphorbiaceae & Ricinus & 1.270 & 14.28 \\
\hline Leguminosae-Papilionoideae & Centrosema & 2.002 & 8.57 \\
\hline Tiliaceae & Triunfeta & 2.665 & 2.86 \\
\hline Anacardiaceae & Spondias & 2.674 & 40.00 \\
\hline Scrophulariaceae & Scoparia & 2.817 & 5.71 \\
\hline Asteraceae & Eupatorium & 4.389 & 65.71 \\
\hline Myrtaceae & Type 1 & 4.657 & 25.71 \\
\hline Myrtaceae & Eucalyptus & 8.568 & 51.43 \\
\hline Cecropiaceae & Cecropia & 13.683 & 74.28 \\
\hline Leguminosae-Mimosoideae & Mimosa pudica & 22.775 & 65.71 \\
\hline Arecaceae & Elaeis & 23.994 & 94.28 \\
\hline
\end{tabular}


Alvarado, J.L. \& Rueda, M.D. 1985. Flora apicola en Uxpanapa, Veracruz, Mexico. Biótica 10: 257-275.

BAHIA. 2002. Sistema de produção de apicultura para o Estado da Bahia: pólen. Salvador. Secretaria de Agricultura, Irrigação e Reforma Agrária do Estado da Bahia.

Borges, R.L.B.; Lima, L.C.L.; Oliveira, P.P.; Silva, F.H.M.; Novais, J.S.; Dórea, M.C. \& Santos, F.A.R. 2006. O pólen no mel do Semi-Árido brasileiro. Pp.103-118. In: Santos, F.A.R. (ed.). Apium plantae. Recife, IMSEAR.

Camillo, E. \& Garófalo, C.A. 1989. Analysis of the niche of two sympatric species of Bombus (Hymenoptera, Apinae) in southeastern Brazil. Journal of Tropical Ecology 5: 81-92.

Carvalho, C.A.L.; Marchini, L.C. \& Ros, P.B. 1999. Fontes de pólen utilizadas por Apis mellifera L. e por algumas espécies de Trigonini (Apidae) em Piracicaba (SP). Bragantia 58: 49-56.

Carvalho, C.A.L.; Moreti, A.C.C.C.; Marchini, L.C.; Alves, R.M.O. \& Oliveira, P.C.F. 2001. Pollen spectrum of honey of "uruçu" bee (Melipona scutellaris Latreille, 1811). Revista Brasileira de Biologia 61: 63-67.

Ertdman, G. 1960. The acetolysis method - a revised description. Sevensk Botanisk Tidskrift 54: 561-564.

Imperatriz-Fonseca, V.L.; Kleinert-Giovannini, A.; Cortopassi-Laurino, M. \& Ramalho, M. 1984. Hábitos de coleta de Tetragonistica angustula Latrielle (Hymenoptera, Apidae, Meliponinae). Boletim de Zoologia da Universidade de São Paulo 8:115-131.

Joosten, H. \& De Klerk, P. 2002. What's in a name? Some thoughts on pollen classification, identification, and nomenclature in Quaternary Palynology. Review of Palaeobotany and Palynology 122: 29-45.

Lima, L.C.L.; Silva, F.H.M. \& Santos, F.A.R. 2008. Palinologia de espécies de Mimosa L. (Leguminosae - Mimosoideae) do Semi-Árido brasileiro. Acta Botanica Brasilica 22: 794-805.

Louveaux, J.; Maurizio, A. \& Vorwohl, G. 1978. Methods of melissopalynology. Bee World 59: 139-157.

Luz, C.F.P.; Thomé, M.L. \& Barth, O.M. 2007. Recursos tróficos de Apis mellifera L. (Hymenoptera, Apidae) na região de Morro Azul do Tinguá, Estado do Rio de Janeiro. Revista Brasileira de Botânica 30: 29-36.

Marques-Souza, A.C.; Absy, M. L.; Condé P.A.A. \& Coelho, H.A. 1993. Dados da obtenção do pólen por operárias de Apis mellifera no município de Ji-Paraná (RO), Brasil. Acta Amazonica 23: 59-76.
Modro, A.F.H.; Message, D.; Luz, C.F.P. \& Meira Neto, A.A. 2007. Composição e qualidade do pólen apícola coletado em Minas Gerais. Pesquisa Agropecuária Brasileira 42: 1057-1065.

Moreti, A.C.C.C.; Carvalho, C.A.L.; Marchini, L.C. \& Oliveira, P.C.F. 2000. Espectro polínico de amostras de mel de Apis mellifera L. coletadas na Bahia. Bragantia 59:1-6.

Mori, S.A.; Carvalho, A.M. \& Santos T.S. 1983. Southern bahian moist forests. 1983. The Botanical Review 49: 155-231.

Novais, J.S.; Lima, L.C.L. \& Santos, F.A.R. 2006. Espectro polínico de méis de Tetragonisca angustula Latreille, 1811 coletados na caatinga de Canudos, Bahia, Brasil. Magistra 18: 257-264.

Novais, J.S.; Lima, L.C.L. \& Santos, F.A.R. 2009. Botanical affinity of pollen harvested by Apis mellifera L. in a semi-arid area from Bahia, Brazil. Grana 48: 224-234.

Oliveira, P.P.; van den Berg, C. \& Santos, F.A.R. 2010. Pollen analysis of honeys from Caatinga vegetation of the state of Bahia, Brazil. Grana 49: 66-75.

Ramalho, M.; Kleinert-Giovannini, A. \& Imperatriz-Fonseca, V.L. 1990. Important bee plants for stingless bees (Melipona and Trigonini) and africanized honeybees (Apis mellifera) in neotropical habitats: a review. Apidologie 21: 469-488.

Ramalho, M.; Silva, M.D. \& Carvalho, C.A.L. 2007. Dinâmica de uso de fontes de pólen por Melipona scutellaris Latreille (Hymenoptera: Apidae): uma análise comparativa com Apis mellifera L. (Hymenoptera: Apidae), no domínio Tropical Atlântico. Neotropical Entomology 36: 28-45.

Roubik, D.W. \& Moreno, J.E. 1991. Pollen and spores of Barro Colorado island. Saint Louis, Missouri Botanical Garden.

Santos Jr., M.C. \& Santos, F.A.R. 2003. Espectro polínico de méis coletados na microrregião do Paraguassu, Bahia. Magistra 15: 79-82.

Silva, F.H.M. \& Santos, F.A.R. 2009. Pollen morphology of the shrub and arboreal flora of mangroves of Northeastern Brazil. Wetlands Ecology and Management 17: 423-443.

Vergeron, P. 1964. Interprétation statistique des résultats en matière d'analyse pollinique des miels. Annales de l'Abeille 7: 349-364.

Wiese, H. 1985. Nova apicultura. $6^{\text {th }}$.ed. Porto Alegre, Agropecuária. 